\title{
A PROFILE OF THE ORGANIC PRODUCE CONSUMER
}

\author{
Martina Zámková, Martin Prokop ${ }^{1}$, Radek Stolín ${ }^{1}$ \\ ${ }^{1}$ Department of Mathematics, College of Polytechnics Jihlava, Tolstého 16, 58601 Jihlava, Czech Republic
}

\begin{abstract}
ZÁMKOVÁ MARTINA, PROKOP MARTIN, STOLÍN RADEK. 2018. A Profile of the Organic Produce Consumer. Acta Universitatis Agriculturae et Silviculturae Mendelianae Brunensis, 66(4): 1043-1052.

Our paper explores the factors influencing the consumers who buy organic food. Analysis of these factors enabled us to sort the consumers into groups based on their gender, age, education, and other identifiers. Further research then revealed more detailed shopping preferences of each one of those groups. The findings generated recommendations for producers and organic produce vendors on the best way to provide target marketing for different groups of consumers and therefore increase their sales of organic produce and food made from organic produce. Considering the use of categorical data, contingency tables and correspondence maps served as the best representation and processing tools.

Data analysis showed that organic produce is most frequently purchased by respondents in the age of $45+$ years, who also tend to spend more money for this range of products. At the same time, these would be the respondents, who struggle the most when recognizing organic produce and who have often never seen any advertisement for it. The respondents aged 25 years and less tend to purchase organic produce least frequently; they also often do not care about the origin of organic produce. Almost the same applies to families with multiple children. However, young respondents often grow their own organic produce. There is still a not insignificant percentage of consumers, who consider organic produce to be expensive and who do not believe in their qualities. As it turns out, when it comes to organic produce the respondents purchase most frequently fruits and vegetables, milk and dairy products.
\end{abstract}

Keywords: organic produce, organic food, consumer profile, organic farming, test of independence, correspondence map, contingency tables, Czech Republic

\section{INTRODUCTION}

The objective of this paper is to provide a detailed profile description of consumers who buy organic food. We have identified several factors influencing the consumers during grocery shopping. At the same time we documented the reasons why some respondents do NOT purchase organic produce. The outcome of our research may inter alia reveal possible marketing measures that would promote the sales of this range of products.

The identification of factors influencing the purchase of organic food has been covered by Kutnohorská (2016), who has carried out an analysis similar to ours. This analysis focused on the Czech Republic. Similarly, Zámková and Prokop (2014) have assessed the consumer behaviour at the organic market in the Czech and Slovak
Republic. The differences between the sales of organic food in Greece and in the Czech Republic were analysed by the pair of authors Zámková and Blašková (2013). The research by Apaolaza et al. (2018) examined inter alia the association between the consumption of organic food and the health priorities of the respondents. Our paper deals with this issue as well-we have been asking our respondents if they consider organic food to be healthier than regular food. The paper by Prada et al. (2017) focused on different perception of organic product characteristics and regular traditional food characteristics as well as on the influence of various environmental messages contained in the media on such perception. This influence often represents the cause of distorted organic food quality perception based on irrelevant attributes. 
Hidalgo-Baz et al. (2017) deal with the issue of food quality, since its definition remains unclear when it comes to organic products. A study carried out by Chalupová et al. (2016) offers findings resulting from a regional food preference analysis in the Vysočina region, Czech Republic, with main focus on awareness analysis of Vysočina region labels. In line with the aforementioned study, our research too posed a question assessing respondents' familiarity with the labelling of organic food.

Krause and Machek (2018) came up with a comparative analysis of organic and conventional farming in the Czech Republic, based on survey conducted on a large sample of organic and conventional farmers. Interestingly, this analysis discovered increased profits that might represent a motivation for more farmers to opt for organic farming. What is more, different income volatility, otherwise often quoted deficiency of organic farming, was not confirmed. Just as surprisingly, the study by Brožová (2011) provided a confirmation of higher profitability in organic farming with her research focusing on a large sample of organic and conventional agricultural subjects. Her work also showed, however, that the good economic results of these enterprises had been significantly affected by the subsidies. Additionally, profitability depends on natural and climatic conditions, as well as on the specific field of activity.

\section{MATERIALS AND METHODS}

In order to obtain the data for our research, we have launched a survey that was conducted at the end of 2017/early 2018. A substantial portion of the respondents was formed by college and high school students studying mainly in the cities of Brno and Jihlava and by older respondents, working in companies of these regions. All of the respondents are from the Czech Republic. The vast majority of the data is categorical and to process them we therefore used exclusively statistical methods suitable for work with lexical variables, such as contingency tables and correspondence analyses.

The character of the data determined the use of corresponding tests of independence. As claimed by Řezanková (1997), for contingency table of the $r \times c$ type ( $r$ is for the number of rows, $c$ is for the number of columns) the Pearson's chi-square test is used most frequently, with the test statistic:

$\chi^{2}=\sum_{i} \sum_{j} \frac{\left(n_{i j}-e_{i j}\right)^{2}}{e_{i j}}$,

where $e_{i j}$ is the expected frequency and, respectively, $n_{i j}$ the observed frequency. The null hypothesis of the test assumes independence. For more details, please see Hindls (2003). In order to use the Pearson's chi-square test, the requirement that maximum $20 \%$ of the expected frequencies are less than five must be complied with, see Hendl (2006) and Agresti (1990). Fisher's exact test was used in other cases; alternatively we calculated the simulated $p$-value of $\chi^{2}$ statistic, see Anděl (2005).

Correspondence analysis is an appropriate method allowing both the display and summary of a set of data in two-dimensional graphic form. This analysis decomposes the chi-squared statistic associated with the Tab. into orthogonal factors. There is a distance between single points which is described as a chi-squared distance. In order to express the distance between $i$ th and $i$ 'th row we use the formula

$D\left(i, i^{\prime}\right)=\sqrt{\sum_{j=1}^{c} \frac{\left(r_{i j}-r_{i^{\prime} j}\right)^{2}}{c_{j}}}$,

where $r_{i j}$ represent the elements of row profiles matrix $\boldsymbol{R}$ and weights $c_{j}$ correspond to the elements of column loadings vector $c^{T}$. The objective of this analysis is to reduce the multidimensional space of both row and column profiles, plus to save maximally original data information, as

I: Contingency table - Column relative frequencies: Do you agree with the subvention of organic farming from the public resources (European and state subsidies)? And Gender.

\begin{tabular}{lcc}
\hline & men & women \\
\hline Yes I agree & $52.63 \%$ & $72.76 \%$ \\
No, I disagree & $23.11 \%$ & $6.58 \%$ \\
I don't know & $24.26 \%$ & $20.66 \%$ \\
\hline
\end{tabular}

Source: own calculation

II: Contingency table - Column relative frequencies: Do you agree with the subvention of organic farming from the public resources (European and state subsidies)? And Age.

\begin{tabular}{lcccc}
\hline & under 25 years & 26-35 years & 36-45 years & 46 or more \\
\hline Yes I agree & $69.61 \%$ & $62.92 \%$ & $60.00 \%$ & $47.37 \%$ \\
No, I disagree & $8.18 \%$ & $16.29 \%$ & $17.78 \%$ & $30.70 \%$ \\
I don't know & $22.21 \%$ & $20.79 \%$ & $22.22 \%$ & $21.93 \%$ \\
\hline
\end{tabular}

Source: own calculation 
suggested by Hebák et al. (2007). The total variance of the data matrix is measured by the inertia; see for example Greenacre (1984). As for the primary data processing - Unistat and Statistica software proved to be very effective.

\section{RESULTS}

Women significantly outnumber men when it comes to the endorsement of subsidies for organic farming, see Tab. I. Significant statistical dependence (Pearson's chi-square test) was proven ( $p$-value is less than 0.001 , chi-square $=78.95$, degrees of freedom $=2$ ). The endorsement rate decreases with the age of respondents; it reaches its lowest value when it comes to respondents of $45+$ years, see Tab. II. Significant statistical dependence (Pearson's chi-square test) was proven ( $p$-value is less than 0.001 , chi-square $=54.98$, degrees of freedom $=6$ ) . The correspondence map (Fig. 1, left) clearly shows that it was mainly the group of respondents over 45 years of age, from whom we have received a negative answer to this question. Mainly the respondents under 25 expressed their approval with subsidies. Further research indicated that the number of respondents agreeing with subsidies slightly decreases with increasing income. Those coming from single-member households tend to be less endorsing as well.

Roughly a quarter of the responses to the question: What is organic food according to you? What do you recall under this term? What do you associate with this term? (see Tab. III) corresponds to the respondents who tend to associate organic food with chemical-free organic farming. More than one tenth of responses was expressed by respondents, who believe organic food to be healthier, more expensive, of higher quality and produced without additives, often coming from free range animals. It may come as a surprise that only $3 \%$ of responses supported the claim that organic food tastes better (some even indicated that it tastes worse), which may be caused by the fact that majority of people is used to the taste of modified food and finds the natural taste of food to be bland.

Analysis of more variables showed that women are more likely to believe in the healthy nature of organic food, while the $45+$ respondents are the most unlikely to trust that. The least inclined to trust the health benefits are the respondents with basic education and from one-member households. People with income over 40,000 CZK believe more than any other group that organic produce is healthier. Women and people with higher education
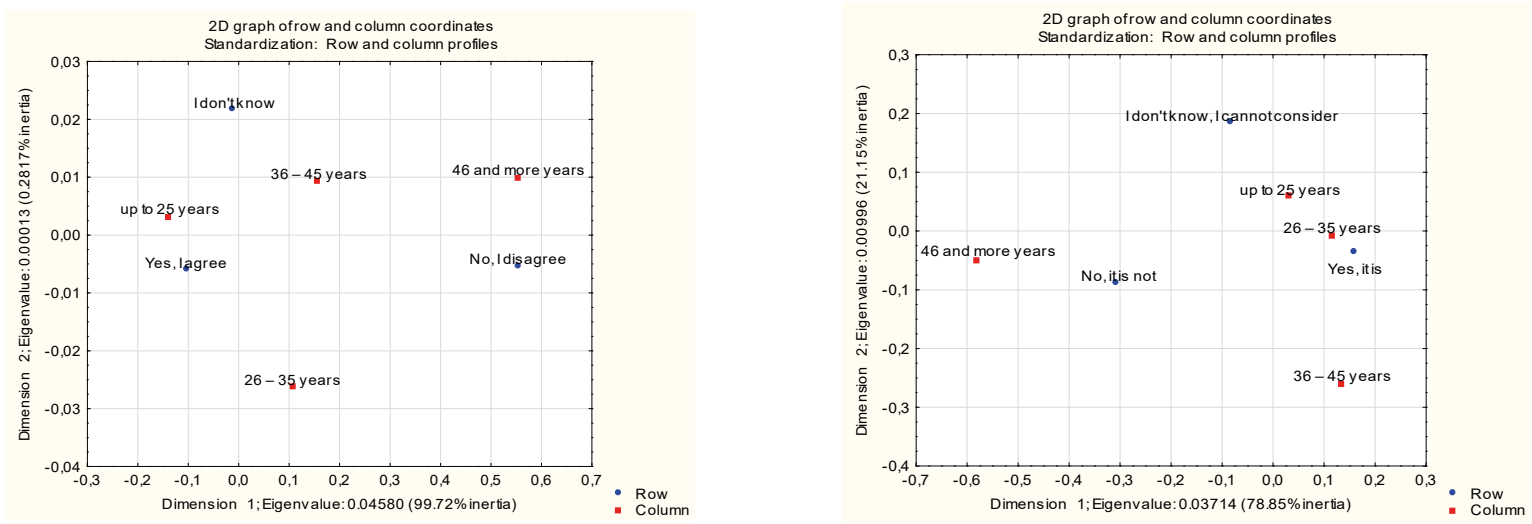

1: Correspondence map: Do you agree with the subvention of organic farming from the public resources (European and state subsidies)? And Age (left); Are you convinced that organic food is sufficiently recognizable in your favourite grocery store? And Age (right) Source: own calculation

III: Relative frequencies: What is organic food according to you? What do you recall under this term? What do you associate with this term?

\begin{tabular}{lc}
\hline Organically grown, without chemicals & $25.46 \%$ \\
Healthy/healthier food & $12.19 \%$ \\
Expensive/more expensive food & $14.51 \%$ \\
Animals in free range, not stressed, nourished without compound & $15.76 \%$ \\
Food without preservatives, emulsifiers, rational nutrition & $13.93 \%$ \\
Food of high quality & $10.54 \%$ \\
It's a lie to entice customers & $3.24 \%$ \\
Food with worse taste & $0.82 \%$ \\
Tastier food & $3.05 \%$ \\
\hline I don't know & $0.51 \%$ \\
\hline Sour: & \\
\hline
\end{tabular}

Source: own calculation 
tend to believe the health benefits of organic food more than men and people with lower education. This confidence seems to be slightly increasing with the income and household size. Women and people with higher education tend to believe that organic food is attractive more than do men and people with lower education. This confidence is slightly increasing along with the income. Women in general seem to be more confident that organic food is of higher quality. The respondents with basic education are the least inclined to trust its superior quality. On the other hand, the respondents with the highest income over 50,000 CZK are the most inclined to trust it.

Men and respondents with the lowest income (under 20,000) are more often the ones who have not yet searched for organic food in stores. The same goes for respondents in the 45+ age group or in the basic education group, who also often do not know whether it is included in store's assortment or not.
Compared to women, men seem to be unable to consider the (in)sufficiency of the labelling of organic produce in stores. The majority of people older than 45 years think that the produce is not sufficiently recognizable, see Tab. IV. Significant statistical dependence (Pearson's chi-square test) was proven ( $p$-value is less than 0.001, chi-square $=56.38, \quad$ degrees of freedom $=6$ ). The correspondence map (Fig. 1, right) indicates that mainly the group of respondents over 45 years of age gave us a negative answer. Younger age groups are more likely to believe that in stores organic products are easily recognizable. And so are respondents with basic education, who are also often not able to consider the recognisability of these products. The promotion of organic produce seems sufficient mainly to younger respondents, under 35 .

Women see advertisements for organic food in the press more often than men, and so do respondents in the 26-45 age group. Younger

IV: Contingency table - Column relative frequencies: Are you convinced that organic food is sufficiently recognizable in your favourite grocery store? And Age.

\begin{tabular}{lcccc}
\hline & under 25 years & 26-35 years & 36-45 years & 46 or more \\
\hline Yes, it is & $55.06 \%$ & $60.11 \%$ & $65.93 \%$ & $28.95 \%$ \\
No, it is not & $20.78 \%$ & $19.10 \%$ & $23.70 \%$ & $45.61 \%$ \\
I don't know, I cannot consider & $24.16 \%$ & $20.79 \%$ & $10.37 \%$ & $25.44 \%$ \\
\hline
\end{tabular}

Source: own calculation

V: Contingency table - Column relative frequencies: Have you ever see an advertising of organic food? And Age.

\begin{tabular}{lcccc}
\hline & under 25 years & $\mathbf{2 6 - 3 5}$ years & $\mathbf{3 6 - 4 5}$ years & 46 or more \\
\hline Yes, on billboards & $0.78 \%$ & $2.25 \%$ & $2.22 \%$ & $5.26 \%$ \\
Yes, in magazine, newspaper & $11.95 \%$ & $24.72 \%$ & $24.44 \%$ & $11.40 \%$ \\
Yes, on TV & $12.99 \%$ & $10.11 \%$ & $15.56 \%$ & $13.16 \%$ \\
Yes, on internet & $24.81 \%$ & $27.53 \%$ & $16.30 \%$ & $12.28 \%$ \\
Yes, I just don't know where it was & $24.55 \%$ & $19.10 \%$ & $19.26 \%$ & $16.67 \%$ \\
I don't know & $9.87 \%$ & $8.43 \%$ & $8.15 \%$ & $5.26 \%$ \\
No, I haven't & $15.06 \%$ & $7.87 \%$ & $14.07 \%$ & $35.96 \%$ \\
\hline
\end{tabular}

Source: own calculation
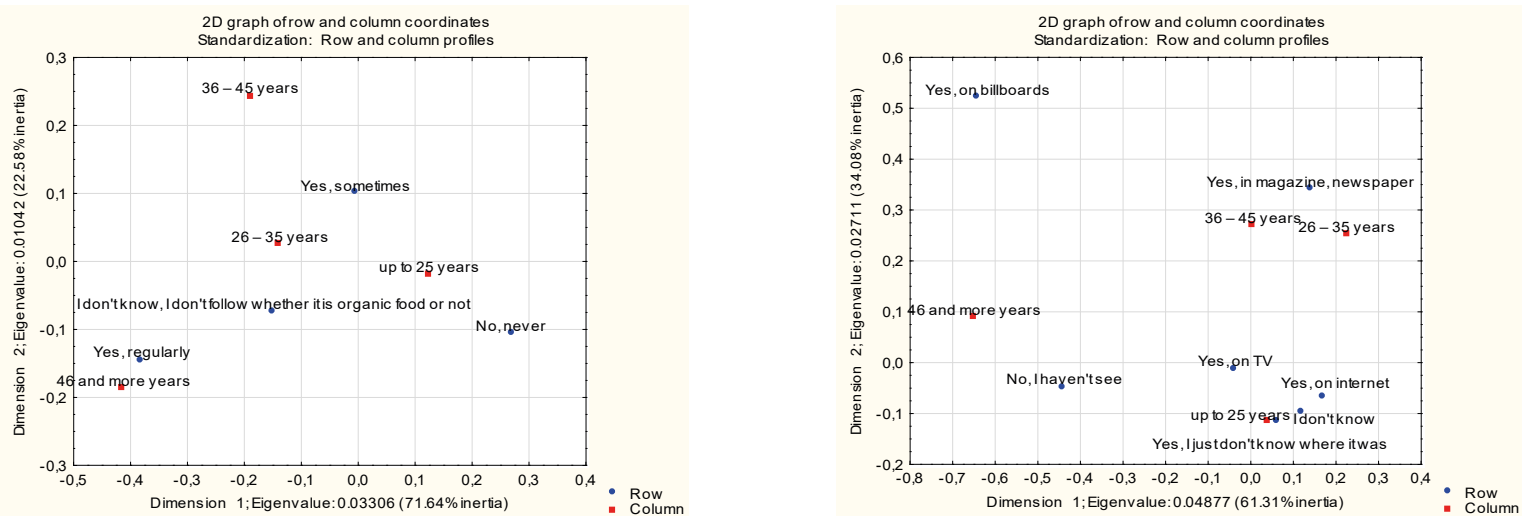

2: Correspondence map: Have you ever see an advertising of organic food? And Age (left)Do you buy organic food in your household? And Age (right) Source: own calculation 
part of the population (under 35) is more likely to encounter such advertisement on the internet. A considerable number of respondents over 45 years say such advertising is nowhere to be seen, see Tab. V. Significant statistical dependence (Pearson's chi-square test) was proven ( $p$-value is less than 0.001 , chi-square $=95.22$, degrees of freedom $=18$ ). The correspondence map (Fig. 2, left) consists of several relatively spaced out groups of both variables. Older respondents do not encounter organic food advertisements so often, the youngest usually see it on-line or on TV, or rather do not remember if or where. Those between 26 and 45 years have seen the ads most frequently in the press. Barely any respondent has seen an ad on a billboard; the point indicating this response is placed quite far away from others. Highly educated respondents see some advertisements in the magazines or newspapers most commonly. The respondents with basic education are the least common to see it on-line. The respondents coming from one-member households are the least likely to ever see any advertisement.

When shopping, men, people over 45, people with basic education, and people from one-member households frequently do not know or follow, whether what they buy is organic. Women are buying groceries more often, see Tab. VI. Significant statistical dependence (Pearson's chi-square test) was proven (p-value is less than 0.001, chi-square $=32.63$, degrees of freedom $=3$ ). When we look at the correspondence map (Fig. 2, right), it is obviously the $45+$ age group that buy organic food regularly most often, sometimes respondents between 36 and 45 years do too. The youngest respondents under age 25 often featured a negative response. Let us emphasize the high proportion of people under 35 and mainly the youngest-under 25, who never buy organic food, see Tab VII. Significant statistical dependence (Pearson's chi-square test) was proven ( $p$-value is less than 0.001 , chi-square $=55.24$, degrees of freedom $=9$ ) . The higher the income, the lower the number of respondents who never buy organic food. The number of respondents who never buy organic food slightly builds up with the increasing number of children. The majority of respondents who never buy organic food live in small villages of fewer than 2,000 inhabitants.

The majority (28\% responses) of the respondents not shopping for organic product claimed the produce is more expensive, see Tab. VIII. More than one-tenth of answers came from responders who do not believe in the qualities of organic produce, consider it unnecessary luxury or find it

VI: Contingency table - Column relative frequencies: Do you buy organic food in your household? And Gender.

\begin{tabular}{lcc}
\hline & men & women \\
\hline Yes, regularly & $8.24 \%$ & $8.95 \%$ \\
Yes, sometimes & $43.71 \%$ & $54.34 \%$ \\
No, never & $21.97 \%$ & $23.55 \%$ \\
\hline I don't know, I don't follow whether it is organic food or not & $26.09 \%$ & $13.16 \%$ \\
\hline
\end{tabular}

Source: own calculation

VII: Contingency table-Column relative frequencies: Do you buy organic food in your household? And Age.

\begin{tabular}{lcccc}
\hline & $\begin{array}{c}\text { under } 25 \\
\text { years }\end{array}$ & $\begin{array}{c}26-35 \text { years } \\
\text { 36-45 years }\end{array}$ & 46 or more \\
\hline Yes, regularly & $6.49 \%$ & $12.92 \%$ & $8.15 \%$ & $17.54 \%$ \\
Yes, sometimes & $49.22 \%$ & $52.81 \%$ & $62.22 \%$ & $41.23 \%$ \\
No, never & $27.66 \%$ & $18.54 \%$ & $10.37 \%$ & $13.16 \%$ \\
\hline I don't know, I don't follow whether it is organic food or not & $16.62 \%$ & $15.73 \%$ & $19.26 \%$ & $28.07 \%$ \\
\hline
\end{tabular}

Source: own calculation

VIII: Relative frequencies: Why don't you buy organic food?

\begin{tabular}{lc}
\hline I have no reason, it has not come to my mind & $13.32 \%$ \\
I don't believe this food is bio, non-chemical, better & $14.46 \%$ \\
I don't know where to buy it, where it is sold & $0.96 \%$ \\
I don't have enough information about organic food & $6.92 \%$ \\
Unnecessary luxury, no difference & $12.18 \%$ \\
Small assortment, it's difficult to come by & $6.49 \%$ \\
Not attractive for me & $14.29 \%$ \\
Financial aspects-organic food is more expensive & $27.96 \%$ \\
\hline I don't know & $3.42 \%$ \\
\hline
\end{tabular}

Source: own calculation 
unattractive. It is satisfactory to find out that only a small proportion of respondents does not know where to get organic food, or finds it difficult to get hold of. This proves the general availability of organic products.

Men and people aged 36-45 buy organic food more often at the mall or in the supermarket, women shop in health and organic food stores, see Tab. IX. Significant statistical dependence (Pearson's chi-square test) was proven ( $p$-value is less than 0.001 , chi-square $=27.15$, degrees of freedom $=5$ ). Higher number of people under 25 grow their own organic produce and that is definitely encouraging. Respondents over 45 years are the most frequent to shop for organic food in small grocery stores, see Tab. X. Significant statistical dependence (Pearson's chi-square test) was proven ( $p$-value is less than 0.001 , chi-square $=54.34$, degrees of freedom $=15$ ). Considering the correspondence map (Fig. 3, left), only older respondents (45+), most frequently shopping for organic produce in small grocery stores, are placed away from the others. Malls and supermarkets became the favourite organic food shopping destination of respondents between 26 and 35 years of age. People under 25 grow their own organic produce more often than every other age group. Basically educated respondents go to malls and supermarkets for organic produce the least while they are the most common to grow it themselves, the same goes for families with 4 or more children. People living in municipalities of under 2,000 inhabitants hardly every shop for organic produce in supermarkets or health food stores, but they are the most likely to grow it themselves or buy it at a farm.

When buying organic food, participants in the survey apparently shop mainly for fruits and vegetables, and also milk and dairy products.

IX: Contingency table - Column relative frequencies: Where do you buy organic food the most? And Gender.

\begin{tabular}{lcc}
\hline & men & women \\
\hline Mall, supermarket & $46.26 \%$ & $32.85 \%$ \\
Health food and organic food stores & $17.62 \%$ & $31.81 \%$ \\
Farms, farmers markets & $11.45 \%$ & $9.15 \%$ \\
I plant it myself & $9.25 \%$ & $12.47 \%$ \\
Smaller grocery stores & $11.01 \%$ & $6.44 \%$ \\
Pharmacies & $4.41 \%$ & $7.28 \%$ \\
\hline
\end{tabular}

Source: own calculation

X: Contingency table - Column relative frequencies: Where do you buy organic food the most? And Age.

\begin{tabular}{|c|c|c|c|c|}
\hline & under 25 years & $26-35$ years & $36-45$ years & 46 or more \\
\hline Mall, supermarket & $34.73 \%$ & $35.90 \%$ & $50.53 \%$ & $35.82 \%$ \\
\hline Health food and organic food stores & $28.90 \%$ & $27.35 \%$ & $23.16 \%$ & $22.39 \%$ \\
\hline I plant it myself & $14.69 \%$ & $5.98 \%$ & $6.32 \%$ & $7.46 \%$ \\
\hline Smaller grocery stores & $5.36 \%$ & $8.55 \%$ & $6.32 \%$ & $25.37 \%$ \\
\hline
\end{tabular}

Source: own calculation


3: Correspondence map: Where do you buy organic food the most? And Age (left)

How much do you spend for organic food for your household per month? And Age (right)

Source: own calculation 
Other products have not appeared in more than 10 percent of responses. The lowest share recorded was achieved by beverages, which means that i.e. organic juices are not that popular.

Men seem to be shopping for organic food as often as women. As for the frequency, there is not a big difference when it comes to age or education either, only respondents over 45 years are the most frequent to buy organic produce several times a week. The lower the income, the lower the frequency of organic food shopping. More people living in municipalities of over 50,000 inhabitants buy organic food several times a week.

There is not a big difference in the amounts usually spent by men and women, but men and respondents younger than 25 often do not know, how much they spend for organic food, see Tab. XI. Significant statistical dependence (Pearson's chi-square test) was proven ( $p$-value is less than 0.001 , chi-square $=16.86$, degrees of freedom $=5$ ) .

XI: Contingency table - Column relative frequencies: How much do you spend for organic food for your household per month? And Gender.

\begin{tabular}{lcc}
\hline & men & women \\
\hline Less than 100 CZK & $11.45 \%$ & $10.60 \%$ \\
$\mathbf{1 0 1 - 5 0 0 ~ C Z K ~}$ & $29.07 \%$ & $41.37 \%$ \\
$\mathbf{5 0 1 - 1 , 0 0 0 ~ C Z K ~}$ & $22.47 \%$ & $22.87 \%$ \\
$\mathbf{1 , 0 0 1 - 2 , 0 0 0 ~ C Z K ~}$ & $8.81 \%$ & $8.52 \%$ \\
More than 2,001 CZK & $7.49 \%$ & $3.74 \%$ \\
\hline I don't know & $20.70 \%$ & $12.89 \%$ \\
\hline
\end{tabular}

Source: own calculation

XII: Contingency table -Column relative frequencies: How much do you spend for organic food for your household per month? And Age.

\begin{tabular}{lcccc}
\hline & under 25 years & $\mathbf{2 6 - 3 5}$ years & $\mathbf{3 6 - 4 5}$ years & 46 or more \\
\hline Less than $\mathbf{1 0 0}$ CZK & $12.59 \%$ & $5.13 \%$ & $16.84 \%$ & $1.49 \%$ \\
$\mathbf{1 0 1 - 5 0 0 ~ C Z K ~}$ & $39.86 \%$ & $44.44 \%$ & $30.53 \%$ & $19.40 \%$ \\
$\mathbf{5 0 1 - 1 , 0 0 0 ~ C Z K ~}$ & $19.35 \%$ & $24.79 \%$ & $23.16 \%$ & $40.30 \%$ \\
$\mathbf{1 , 0 0 1 - 2 , 0 0 0 ~ C Z K ~}$ & $3.73 \%$ & $12.82 \%$ & $12.63 \%$ & $26.87 \%$ \\
More than 2,001 CZK & $3.73 \%$ & $5.13 \%$ & $7.37 \%$ & $8.96 \%$ \\
I don't know & $20.75 \%$ & $7.69 \%$ & $9.47 \%$ & $2.99 \%$ \\
\hline
\end{tabular}

Source: own calculation

XIII: Contingency table - Column relative frequencies: In assortments of available organic products there prevail products of: And Age.

\begin{tabular}{lcccc}
\hline & under 25 years & $\mathbf{2 6 - 3 5}$ years & $\mathbf{3 6 - 4 5}$ years & 46 or more \\
\hline Domestic production & $40.09 \%$ & $44.44 \%$ & $63.16 \%$ & $56.72 \%$ \\
Foreign production & $16.55 \%$ & $9.40 \%$ & $1.05 \%$ & $23.88 \%$ \\
Regional production & $12.12 \%$ & $31.62 \%$ & $34.74 \%$ & $14.93 \%$ \\
I don't know & $31.24 \%$ & $14.53 \%$ & $1.05 \%$ & $4.48 \%$ \\
\hline
\end{tabular}

Source: own calculation

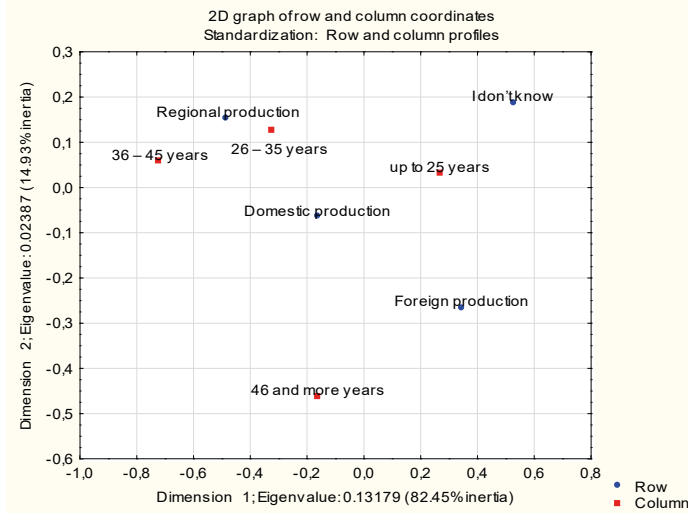

4: Correspondence map: In assortments of available organic products there prevail products of: And Age Source: own calculation 
Respondents over 45 years of age of all categories spend over $500 \mathrm{CZK}$ per month more than others, see Tab. XII. Significant statistical dependence (Pearson's chi-square test) was proven ( $p$-value is less than 0.001 , chi-square $=101.88$, degrees of freedom $=15$ ). The correspondence map (Fig. 3, right) clearly indicates that mainly the group of respondents over 45 years of age is placed around the highest spendings. The rest of the age groups do not show such an obvious pattern. The amount spent usually increases with increasing income. Only people living in big cities of over 20,000 inhabitants tend to spend over 2,000 CZK.

The majority of people under 25, people with income under 30,000 CZK, and people coming from families with 4 or more children do not know, if the organic produce is of domestic or foreign production, see Tab. XIII. Significant statistical dependence (Pearson's chi-square test) was proven ( $p$-value is less than 0.001, chi-square $=113.17$, degrees of freedom $=9$ ). The group of respondents aged 26 to 45 years often stated, that available organic food comes from regional or domestic production. As seen in the correspondence map (Fig. 4) respondents under 25 are often simply not interested in the origin of organic food. Older respondents do not show any strong pattern considering this issue; they are placed in a remote position in the graph.

Respondents from the Czech Republic are familiar with the label of Czech organic food (33.3\%) and the European label is nothing strange for them either (26.5\%). Many respondents also know the German label (21\%). A smaller number of respondents have encountered the Slovak label (12.2\%) and the lowest number of them have ever seen the Austrian one (7\%). This may be due to low import volumes from these countries, accounting for only a negligible part of the assortment in stores selling organic products.

\section{DISCUSSION}

The paper by Prada et al. (2017) found out that respondents perceive original unprocessed organic products as healthier, tastier, and more environmentally friendly than conventional food; however, the difference was not so significant with regard to organic food made from organic produce. We have considered organic food as a whole and we have found out that only a small proportion of respondents consider organic food to be tastier, while a significant number of them appreciate chemical-free environmentally friendly farming. Hidalgo-Baz et al. (2017) demonstrated that the association between the protection of the environment and health has positive impact on the perception of quality. We too have looked into the matter of perception and our research showed that in roughly $10 \%$ of the answers, the respondents believe in superior quality of organic food, but the same proportion of answers was given by the respondents, who do not believe in it.
In his study, Janssen (2018) focused on factors influencing the attitude of respondents with regard to organic food and the amount of money spent for it. Here he found discrepancies considering the attitude towards the quality of organic food and the actual behaviour of consumers. Models created with the use of structural equations indicated important attributes for both the attitude and the purchases of organic products (only with different relative significance) and these include naturalness, healthiness and quality of food, protection of the environment, and local domestic origin. Not insignificant number of participants in our survey also consider organic food to be healthier and of superior quality, plus show interest in its place of origin.

Zámková and Prokop (2014) proved that the number of Czech and Slovak respondents shopping for organic food regularly is only negligible. Our research have similarly demonstrated that there are very few young people who buy organic products regularly and these were also the ones, who most often claimed they do not buy organic food at all. This implies that marketing strategies targeting people under 25 need to change, since these are the consumers who will be shopping for groceries in many years to come. The work Zámková and Blašková (2013) - similarly to our own analysis-proved that Czech and Slovak respondents prefer to buy organic food at the malls or supermarkets. Our research proved that it applies mainly to men. According to our results, women on the other hand often buy organic food in health food stores.

Furthermore, we found out that the majority of respondents of the $45+$ group believe that organic food in stores is unrecognisable. This proven fact may serve as a motivation for organic food producers to provide packaging and labelling with clear, comprehensible and legible descriptions, so that the products are easily recognizable by older generation that often struggles with vision problems. Our research also clearly shows that younger respondents under 35 years encounter the advertising for organic food mostly on the internet or in the press. At the same time, we have found that a great number of respondents over 45 years of age have never seen any advertising for organic food. The producers and vendors of organic food trying to achieve efficient advertising should therefore focus on ads in the press, on TV and on the internet, where various target groups would most likely notice, plus, on-line advertising should be tailored for younger consumers and advertising in the newspapers and on TV should be tailored for older generation. They could possibly even come up with an appealing on-line ad targeting older consumers, since they are using this new media more and more. Conversely, it would be worthless to invest in billboards, since the respondents are clearly not following this type of advertising.

Based on the analysis it is obviously the $45+$ age group that buy organic food regularly most often, 
sometimes respondents between 36 and 45 years. The youngest respondents (under 25) often do not buy organic food at all. We would therefore once again recommend to focus on advertising that would be targeting the aforementioned groups of consumers. Our research also showed that older respondents buy organic food most frequently compared to all of the other age groups. It is therefore advisable to focus on advertisements targeting younger consumers and families with multiple children, who surprisingly buy organic food least frequently. They either do not worry about their well-being, which is alarming, especially considering young respondents and children, or they do not believe that organic food is healthier than regular food. We have additionally proved that mainly respondents older than 45 like shopping in smaller grocery stores. Thus it would be only fitting to give the producers a recommendation to include their products not only in specialized stores' offer, but also in the corner shops and small grocery stores. These stores are frequented by the older generation of consumers and this customer base is growing due to ageing of population-they represent a strong purchasing power. On the negative side, young people and families with multiple children often do not care about the origin of organic food. This shows how marketing campaigns promoting advantages of local produce do not work on these groups of customers. Young people and children may carry this lack of interest into the future and it can even spread and affect other generations; it is necessary to Fig. out the best approach and promote domestic organic and non-organic local produce more.

\section{CONCLUSION}

The objective of our study was to describe the consumer behaviour at the organic produce market. The consumers were sorted into groups based on several identifiers (gender, age, education). As a sub-objective, we intended to use our findings and formulate different marketing strategies in order to motivate specific consumer groups to buy organic food.

According to our research, significantly more women than men agree with subsidies into organic farming. The endorsement rate however decreases with the age of respondents; it reaches its lowest value when it comes to respondents of $45+$ years. The number of respondents agreeing with subsidies for organic farming surprisingly slightly decreases with increasing income. The majority of respondents tend to associate organic food with chemical-free organic farming. More than one tenth of responses has been expressed by respondents, who believe organic food to be healthier, more expensive, of superior quality and produced without additives, often coming from free range animals. Our research has furthermore proved that the majority of respondents of the 45+ group believe that organic food in their favourite store is not sufficiently recognisable. The promotion of organic produce seems sufficient enough mainly to younger respondents, under 35. According to the analysis, women see advertisements for organic food in the press more often than men, and so do respondents in the 26-45 age group. Younger part of the population (under 35) encounters advertisements for organic produce predominantly on the internet. A considerable number of respondents over 45 years say organic food advertising is nowhere to be seen. Our research made it also evident that women more often believe that organic produce is tastier, more attractive and of superior quality.

Based on the data it is undoubtedly the 45+ age group that buys organic food regularly most often, respondents between 36 and 45 years buy it sometimes. Let us emphasize the high proportion of people under 35 and mainly the youngest-under 25, who never buy organic food. The majority of respondents who never buy organic food live in small villages of under 2,000 inhabitants. Many respondents consider organic produce to be more expensive, more than one-tenth of answers came from responders who do not believe in the qualities of organic produce, consider it unnecessary luxury or find it unattractive. Men and people aged 36-45 buy organic food more often at the mall or in the supermarket, women shop in health and organic food stores. People under 25 grow their own organic produce more often than every other age group. Respondents over 45 years are the most frequent to shop for organic food in small grocery stores. When buying organic food, participants in the survey apparently shop mainly for fruits and vegetables, and also milk and dairy products. The analysis further suggested that men seem to be shopping for organic food as often as women. As for the frequency, there is not a big difference when it comes to age or education either, only respondents over 45 years are the most frequent to buy organic produce several times a week. It also became evident that there is not a big difference in the amounts usually spent by men and women, but men and respondents younger than 25 often do not know how much they spend for organic food. Respondents over 45 years of age of all categories spend over 500 CZK per month more than others. The group of respondents aged 26 to 45 years stated that available organic food comes from regional or domestic production. Respondents under 25 are often simply not interested in the origin of organic food, according to the research.

The final part of our research focused on customers' familiarity with organic food labelling in various EU member states. Respondents from the Czech Republic are familiar with the label of Czech organic 
food (33.3\%) and the European label is nothing strange for them either (26.5\%). Surprisingly many respondents also know the German label (21\%). A smaller number of respondents have encountered the Slovak label (12.2\%) and the lowest number of them have ever seen the Austrian one (7\%). All tested dependencies have appeared to be statistically dependent ( $p$-value is less than 0.001).

\section{REFERENCES}

AGRESTI, A. 1990. Categorical Data Analysis. New York: John Wiley a Sons.

ANDĚL, J. 2005. Mathematical statistics [in Czech: Základy matematické statistiky]. Praha: Matfyzpress.

APAOLAZA, V., HARTMANN, P., D'SOUZA, C. and LÓPEZ, C. M. 2018. Eat organic - Feel good? The relationship between organic food consumption, health concern and subjective wellbeing. Food Quality and Preference, 63: 51-62.

BROŽOVÁ, I. 2011. The economic performance analysis of organic farms in the Czech Republic. Agricultural Economics, 57(5): 240-246.

GREENACRE, M. J. 1984. Theory and Applications of Correspondence Analysis. London: Academic Press.

HEBÁK, P. et al. 2007. Multivariate statistical methods 3 [in Czech: Vicerozmèrné statistické metody 3]. Praha: Informatorium.

HENDL, J. 2006. Summary of statistical methods: analysis and meta-data [in Czech: Přehled statistických metod: analýza a metaanalýza dat]. Praha: Portal.

HIDALGO-BAZ, M., MARTOS-PARTAL, M. and GONZÁLEZ-BENITO, Ó. 2017. Assessments of the quality of organic versus conventional products, by category and cognitive style. Food Quality and Preference, 62: 31-37.

HINDLS, R. 2003. Statistics for Economists [in Czech: Statistika pro ekonomy]. $3^{\text {rd }}$ compl. edition. Praha: Professional Publishing.

CHALUPOVÁ, M., PROKOP, M. and ROJÍK, S. 2016. Regional Food Preference and Awareness of Regional Labels in Vysočina Region (Czech Republic). European Countryside, 8(2): 109-122.

JANSSEN, M. 2018. Determinants of organic food purchases: Evidence from household panel data. Food Quality and Preference, 68: 19-28.

KRAUSE, J. and MACHEK, O. 2018. A comparative analysis of organic and conventional farmers in the czech republic. Agricultural Economics, 64(1): 1-8.

KUTNOHORSKÁ, O. 2016. Factors influencing organic food buying behavior on Czech market. In: Proceedings of the 28th International Business Information Management Association Conference - Vision 2020: Innovation Management, Development Sustainability, and Competitive Economic Growth. 9-10 November, Seville, Spain. International Business Information Management Association, pp. 2839-2841.

PRADA, M., GARRIDO, M. V. and RODRIGUES, D. 2017. Lost in processing? Perceived healthfulness, taste and caloric content of whole and processed organic food. Appetite, 114: 175-186.

ŘEZANKOVÁ, H. 1997. Categorical data analysis using SPSS [in Czech: Analýza kategoriálních dat pomocí SPSS]. Praha: VŠE.

ZÁMKOVÁ, M. and BLAŠKOVÁ, V. 2013. The differences in the marketability of organic products in Greece and the Czech Republic. Agricultural Economics, 59(5): 219-226.

ZÁMKOVÁ, M., PROKOP, M. 2014. Comparison of consumer behavior of Slovaks and Czechs in the market of organic products by using correspondence analysis. Acta Universitatis Agriculturae et Silviculturae Mendelianae Brunensis. 62(4), 783-795.

Martina Zámková: martina.zamkova@vspj.cz

Martin Prokop: martin.prokop@vspj.cz

Radek Stolín: radek.stolin@vspj.cz 